\title{
IMPLEMENTASI PENDIDIKAN KARAKTER YANG BERWAWASAN PANCASILA DI MAN 4 SLEMAN YOGYAKARTA
}

\author{
Zikry Septoyadi ${ }^{1}$, Vita Lastriana Candrawati ${ }^{1}$ \\ ${ }^{1}$ Pendidikan Agama Islam, Fakultas IImu Agama Islam, Universitas Islam Indonesia \\ Yogyakarta
}

\begin{abstract}
ABSTRAK
Latar belakang penelitian ini adalah Setelah merdeka lebih dari 75 tahun, Indonesia banyak meraih kemajuan di dalam bidang politik, ekonomi, sosial-budaya, dan keagamaan. Namun, energi yang positif itu sampai batas tertentu terbuang sia-sia karena ketidaksungguhan dan berbagai kesalahan kolektif yang telah ditimbulkan, sehingga bangsa ini mengalami yang dinamakan krisis dimensional, di mana masalah pada satu aspek bidang juga akan mempengaruhi bidang lain, misalnya terjadi masalah pada aspek pendidikan akan berimbas pada masalah ekonomi maupun politik, begitu juga sebaliknya yang mengarah secara signifikan pada melemahnya visi dan karakter bangsa. Kemudian jika kita melihat lebih luas lagi, ancaman paling berbahaya yang sedang dialami bangsa Indonesia saat ini adalah "Brainwash", atau yang dikenal dengan cuci otak, hal ini dilakukan untuk mengontrol pikiran seseorang, karena dari sinilah awal mula gejala terorisme, radikalisme, kerusuhan massal, aksi bom bunuh diri, anarkis, dll. Yang kesemuanya dapat dengan mudah bertumbuh kembang dengan memanfaatkan ketidakadilan sosial, penindasan, kesenjangan ekonomi, rendahnya pendidikan, tidak percaya pada pemerintah, wilayah gerak pemerintah yang sangat luas, perbedan suku, agama, ras, isu HAM, serta ketidakpercayaan pada demokrasi. Penelitian ini adalah penelitian lapangan field research yang bersifat kualitatif. Teknik pengumpulan data menggunakan teknik observasi, wawancara, dan dokumentasi.Hasil penelitian dapat di simpulkan bahwa MAN 4 Sleman sudah sejalan dengan nilai-nilai wawasan kebangsaan Pancasila, MAN 4 Sleman menerapkan kontruksi filosofis nilai-nilai pancasila di dalam sekolah dengan menggunakan berbagai hal yang di lakukan oleh guru maupun kepala sekolah seperti religius, jujur, toleransi, dispilin, kerja keras, kreatif, mandiri, demokratis, rasa ingin tahu, semangat kebangsaan, cinta tanah air, bersahabat komunikatif, cinta damai, gemar membaca, peduli lingkungan, peduli sosial, tanggung jawab sudah menjadi agenda program pendidikan karakter yang ada di MAN 4 Sleman.
\end{abstract}

Kata kunci : Intoleransi, Wawasan Kebangsaan (Pancasila)

\begin{abstract}
The background of this research is that after being independent for more than 75 years, Indonesia has made a lot of progress in the political, economic, socio-cultural and religious fields. However, this positive energy is to a certain extent wasted due to the indifference and various collective mistakes that have been caused, so that this nation experiences what is called a dimensional crisis, where problems in one aspect of the field will also affect other fields, for example a problem occurs in the education will have an impact on economic and political problems, and vice versa which will lead to a significant weakening of the nation's vision and character. Then if we look more broadly, the most dangerous threat that is currently being experienced by the Indonesian people is "Brainwash", or what is known as brainwashing, this is done to control one's mind, because this is where the symptoms of terrorism, radicalism, and mass riots began. , suicide bombings, anarchists, etc. All of which can easily grow and develop by taking advantage of social injustice, oppression, economic inequality, low education, distrust of the government, a very large area of government movement, differences in ethnicity, religion, race, human rights issues,
\end{abstract}


and distrust in democracy. This research is a qualitative field research field research. The data collection techniques used observation, interview, and documentation techniques. The results of the study can be concluded that MAN 4 Sleman is in line with the values of the Pancasila national insight, MAN 4 Sleman applies the philosophical construction of Pancasila values in schools by using various things Do it by teachers and school principals such as religious, honest, tolerance, discipline, hard work, creative, independent, democratic, curiosity, national spirit, love for the country, communicative friends, love peace, love to read, care for the environment, care for the social, responsibility has become the agenda of the character education program in MAN 4 Sleman.

Keywords: Intolerance, Nationality Insight (Pancasila)

\section{PENDAHULUAN}

Kekaburan visi dan melemahnya karakter bangsa menjadi beban nasional yang berat ketika berakumulasi dengan berbagai persoalan internal yang kompleks pada tubuh bangsa ini ${ }^{[1]}$. Salah satu kekaburan visi di atas dapat dilihat dari perilaku intoleransi berbasis SARA di tengah masyarakat termasuk di sekolah yang akhir-akhir ini marak terjadi. Wajah umat beragama tidak terkecuali Islam tampak mengejutkan sekaligus memiriskan, dengan banyaknya kasus kekerasan dan ancaman bom dengan membawa-bawa nama agama (Islam).

Sebut saja kasus teror bom buku di awal April 2011, bom Cirebon di pertengahan bulan April 2011, dan fenomena penculikan yang dikatakan dengan metode brain washing atau cuci otak yang diberitakan banyak media berkaitan dengan NII (Negara Islam Indonesia). Kasus-kasus ini semua membawa nama ajaran Islam tertentu, seperti syahid, jihad, pemberlakuan syariat Islam, melawan thâghût (setan dalam bentuk manusia), dan lain-lain. Tidak hanya itu, data yang dihimpun oleh Wahid Institute tahun 2010, menunjukkan dengan jelas grafiknya tidak semakin menurun. Wahid Institute mencatat selama 2010 ada 63 kasus, dengan rata-rata terjadi 5 kasus perbulan, dan kasus tertinggi terjadi pada bulan Januari (12 kasus), Agustus (8 kasus) dan September (7 kasus). Korban dari berbagai tindakan kekerasan, karena perbedaan agama, keyakinan dan intoleransi ini berjumlah 153 korban, baik individu atau kelompok. Dalam data penelitian dari salah satu Lembaga Kajian Islam dan Perdamaian (LaKIP) tentang radikalisme. Penelitian dilakukan pada bulan Oktober 2010 hingga Januari 2011 lalu terhadap siswa dan guru Pendidikan Agama Islam (PAI) di Jabodetabek. Metode yang dilakukan yakni dengan survei melalui wawancara tatap-muka dengan panduan kuesioner. Dari hasil penelitian itu diketahui : Kecenderungan Radikalisme Ideologis Tingkat pengenalan atas organisasi radikal, guru PAI $66,4 \%$, siswa $25,7 \%$, Tingkat kesetujuan atas organisasi radikal, guru PAI 23,6 \%, siswa $12,1 \%$, Tingkat pengenalan pada tokoh radikal, guru PAI 59,2 \%, siswa 26,6 \%, Tingkat kesetujuan kepada tokoh radikal, guru PAl 23,8 \%, siswa 13,4 \% ${ }^{[2]}$. Sudah harus menjadi perhatian bersama untuk kita renungi barang tentu gerakan konflik SARA akan menggerogoti keutuhan NKRI, padahal jauh berabad-abad penghuni bumi Nusantara adalah sebangsa.

Pendidikan karakter yang saat ini dijalankan sekadar berdampak kesolehan ritual. Dampaknya mudah terpropokasi terlebih oleh isu berbau SARA. Dunia pendidikan khususnya pendidikan agama dan karakter seharusnya mampu menjadi solusi memecahkan berbagai persoalan di atas. Keduanya pada hakikatnya sebagai salah satu upaya pendewasaan manusia pada dimensi spiritual-religius dan moral. Adanya pelajaran agama dan pendidikan karakter di satu pihak sebagai upaya pemenuhan hakekat manusia sebagai makhluk religius (homo religiousus) dan makhluk moralis. Sekaligus pemenuhan apa yang objektif dari para siswa akan kebutuhan pelayanan hidup keagamaan. Agama dan hidup beriman merupakan suatu yang objektif menjadi kebutuhan setiap manusia. 
Dalam konteks di atas menarik untuk di teliti lebih lanjut problem yang terjadi belakangan ini yang sedang marak di kalangan akademisi maupun masyarakat. Berbagai peristiwa seperti peserta didik melawan guru serta para siswa yang masih duduk di bangku MI, MAN dan MTS menjadi anggota geng motor, anak yang membunuh ibunya sendiri dan lain-lain. Dengan demikian ada diskursus terhadap konstruksi filosofi pendidikan karakter yang di jalani di sekolah selama ini. Berdasarkan observasi awal peneliti di salah satu sekolah tingkat MAN, yaitu MAN 4 Sleman data: penerapan yang dilakukan oleh sekolah dalam menjalankan roda pendidikan telah sesuai dengan "Permendikbud 22 tahun 2016" tentang Standar proses, akan tetapi dari sisi karakter yang di bangun oleh sekolah tidak memiliki kekhasan karakter yang berlandaskan dari nilai-nilai Pancasila tidak terlihat secara signifikan, sehingga ada kekaburan karakter di sekolah tingkat MI, MAN bahkan Sampai MTS. Beberapa kasus yang sering di jumpai di tingkat MAN seperti kekerasan, merokok dan mabuk- mabukan, tawuran, perampokan, pemalakan dan lain- lain. Oleh karenanya peneliti tertarik mengkaji lebih jauh di sekolah tersebut. Kajian difokuskan pada konstruksi filosofi dari pendidikan karakter yang selama ini diimplementasikan di MAN 4 Sleman. Riset ini semakin menarik karena MAN 4 Sleman ini berada di pelosok, jauh dari kehidupan kota maupun metropolitan harusnya relative steril dari kenakalan -kenakalan di atas. Namun ternyata, meskipun plosok, prilaku kenakalan peserta didik di sekolah tersebut justru tidak kalah dengan sekolah-sekolah yang ada diperkotaan yang secara pergaulan harusnya lebih resisten.

Kekhasan dalam penelitian ini adalah ingin merumuskan konten pendidikan karakter yang menekankan pada visi-visi kebangsaan. Pendidikan karakter yang tidak saja saleh secara ritual (religius) tapi juga saleh secara sosial, dan kebangsaan. $\mathrm{Di}$ tengah menguatnya paham radikalisme, kekerasan berbasis isu SARA dan intoleransi di tengah masyarakat khususnya kalangan muda Indonesia, pendekatan berbasis nilai kebangsaan dan pancasila untuk memecahkan problem-problem radikalisme, kekerasan berbasis SARA dan intoleransi sangatlah penting. Termasuk dalam hal isu radikalisme yang terjadi dalam dunia pendidikan.

\section{METODE PENELITIAN}

Metode yang digunakan dalam penelitian ini adalah metode kualitatif yaitu meliputi kegiatan pengamatan, wawancara atau penelaahan dokumen ${ }^{[3]}$ Metode kualitatif lebih menekankan analisisnya pada proses penyimpulan deduktif dan induktif serta pada analisis terhadap dinamika hubungan antar fenomena yang diamati, dengan menggunakan logika ilmiah ${ }^{[4]}$.

Pendekatan dalam penelitian ini menggunakan deskriptif kualitatif, yaitu penelitian yang bertujuan menggambarkan secara sistematik dan akurat fakta dan karakteristik mengenai populasi atau mengenai bidang tertentu. Penelitian ini berusaha menggambarkan situasi dan kejadian ${ }^{[5]}$. Dalam melaksanakan penelitian ini, peneliti pengambil tempat di MAN 4 Sleman, yang beralamat di Dero Wetan, Harjobinangun, Kec. Pakem, Sleman, Yogyakarta. Dengan pertimbangan : Tersedia data untuk memecahkan masalah dalam penelitian ini. Subjek dalam penelitian ini adalah siswa, guru, dan komite sekolah di tingkat MAN. Subjek merupakan Kepala Sekolah, 20 siswa, 5 guru dan 5 komite Madrasah tingkat MAN yang berjumlah 30 orang. Data yang di gunakan adalah data primer, dengan mewawancarai siswa, guru, dan komite sekolah secara langsung mengenai seputar Nilai-Nilai Pancasila dan kebangsaan. Tahapan pertama, akan dilakukan tinjauan langsung dengan mewawancarai beberapa siswa, guru, dan komite sekolah di MAN 4 Sleman. Tahapan kedua diberikan lembar evaluasi atau post test kepada siswa, guru, dan komite sekolah. Melakukan analisis terhadap hasil wawancara dan lembar evaluasi.

Pada penelitian ini, untuk mengetahui keabsahan data, penulis menggunakan teknik triangulasi. Triangulasi merupakan suatu teknik pengumpulan data yang bersifat menggabungkan dari berbagai teknik pengumpulan data dan sumber data yang telah ada ${ }^{[6]}$. Jika melakukan pengumpulan data dengan triangulasi, maka sebenarnya peneliti 
mengumpulkan data sekaligus menguji kredibilitas data, yaitu mengecek kredibilitas data dengan berbagai teknik pengumpulan data dan berbagai sumber data $^{[7]}$

Dalam proses ini kegiatan yang pertama adalah proses pengumpulan data. Sebagian besar data kualitatif adalah data yang berupa kata-kata, fenomena, foto, sikap, dan perilaku keseharian yang diperoleh peneliti dari hasil observasi mereka dengan menggunakan beberapa teknik seperti obeservasi, wawancara, dokumentasi dan dengan menggunakan alat bantu yang berupa kamera, video tape ${ }^{[8]}$.

\section{HASIL PENELITIAN DAN PEMBAHASAN}

Kontruksi filosofi nilai-nilai pancasila yang selama ini di laksanakan di MAN 4 Sleman, mencakup kegiatan yang bersifat pembinaan karakter peserta didik yang di lakukan secara rutin, spontan, dan keteladanan. Selain di berikan secara integral dalam proses pembelajaran semua mata pelajaran di kelas, nilai-nilai pancasila juga di berikan melalui kegiatan pembiasaan dalam kehidupan sehari-hari sepanjang waktu belajar di madrasah dan dilaksanakan melalui pendidikan praktik ilmu-ilmu keagamaan dan kepancasilaan yang terjadwal dan bertarget. Seluruh pendidik dan pembimbing ditugaskan untuk membina program yang telah diterapkan oleh madrasah. Program pendidikan karakter di MAN 4 Sleman : Religius, jujur, toleransi, disiplin, kerja keras, kreatif, mandiri, demokratis, rasa ingin tahu, semangat kebangsaan, cinta tanah air, menghargai prestasi, bersahabat komunikatif, cinta damai, gemar membaca, peduli lingkungan, peduli sosial, dan tanggung jawab ${ }^{[9]}$. Kontruksi filosofi nilai-nilai pancasila di MAN 4 Sleman dengan menyatu padukan antara nilai-nilai keislaman dan keindonesiaan yang sudah tercermin di dalam program yang ada di madrasah.

Berdasarkan pengamatan peneliti mengenai konstruksi nilai-nilai Pancasila yang selama ini di laksanakan di MAN 4 Sleman, sudah ada bentuk konkrit dalam menumbuhkan karakter murid yang saleh spritual dan saleh sosial. Pertama, adanya solat dzuhur berjamaah salah satu pendorong murid dalam menanamkan karakter nilai-nilai keislaman yang tumbuh pada karakter murid yang memiliki akhlakul karimah yang baik, kaitan dengan filsafat antropologi "eksistensialisme" dengan sila 1 Pancasila yaitu maka yang berhubungan dengan sila pertama di sini yakni "ketuhanan yang maha esa", adalah sejauh menyangkut persoalan "subyektifitas". Dikatakan subyektif karena pengalaman ketuhanan itu merupakan pengalaman kesadaran langsung individu manusia yang sifatnya privat, dan sama sekali tidak bisa disamakan dengan orang lain, karena setiap orang dalam mengeksplorasi pengalamannya pasti berbeda-beda ${ }^{[10]}$. Meski pengalaman manusia tidaklah sama, termasuk pengalaman langsung tentang ketuhanan, akan tetapi manusia masih bisa saling berbagi tentang pengalaman itu sendiri melalui "komunikasi". Komunikasi mempunyai posisi penting di sini, akan tetapi menjadi lain lagi masalahnya jika persoalan ketuhanan menjadi bahan perdebatan (dalam makna yang negatif), sebab ketuhanan bukan untuk diperdebatkan, melainkan hanya perlu dirasakan kehadiran-Nya dalam jiwa-jiwa kita, di sinilah nilai-nilai dari sila pertama akan mendapatkan tempatnya yang pas bahwa masalah ketuhanan memang sangatlah privat adanya. Dalam ruang publik, sebagaimana negara Indonesia mengakui enam agama beserta Penghayat Kepercayaan yang ada, maka dalam kehidupan beragama tidaklah perlu masing-masing agama saling mengedepankan politik identitas, karena dikhawatirkan akan menimbulkan perpecahan di dalam tubuh NKRI, yang perlu diekspresikan dalam ruang publik adalah esensi dari ajaran agama itu sendiri dan bukan identitas keagamaannya, bahwa setiap agama harus mengalami subtansialisasi ketika berada di ruang publik.

Kedua, saling bergotong royong dalam melakukan aksi peduli sosial maupun memfasilitasi kegiatan yang bersifat sosial. Dalam kaitan dengan Pancasila terdapat pada sila ke 2 "kemanusiaan yang adil dan beradab", di dalam pemikiran eksistensialisme sangat erat kaitannya dengan "humanisme" yang selalu memuliakan harkat dan martabat manusia. Humanisme ala Indonesia 
tidaklah sama dengan Humanisme Barat, karena bangsa Indonesia mempunyai pengalaman kesejarahan yang berbeda dengan apa yang terjadi di dunia Barat, selain itu kultur bangsa Indonesia juga berbeda dengan kultur Barat. Humanisme ala Indonesia tidaklah mengenal yang namanya "individualisme", seperti yang sudah dijelaskan sebelumnya di atas, melainkan sebuah bangsa yang bersifat kekeluargaan dan selalu mengedepankan gotong-royong. Bahkan seperti halnya Hak Asasi Manusia, Indonesia lebih dulu mendeklarasikan daripada PBB yang baru mendeklarasikan dua tahun setelah Indonesia Merdeka, yakni pada tahun 1947. Dalam pandangan eksistensialisme, bahwa yang terpenting dari alam semesta adalah faktor manusia ${ }^{[11]}$, melalui pengertian ini diharapkan manusia ditempatkan pada kedudukan yang tinggi yaitu pada kepentingan manusia itu sendiri dan nilai-nilai kemanusiaan. Memang HAM adalah hak manusia universal, akan tetapi secara penerapannya pada masing-masing negara adalah secara particular.

Ketiga, cinta damai, perilaku sopan santun, bersahabat komunikatif dan peduli lingkungan. Hal ini yang tercermin di dalam suasana ketika berada di dalam MAN 4 Sleman yang membuat sejuk dalam pembicaran dialog bersama guru, murid dan staf karyawan MAN 4 Sleman. Dalam peduli lingkungan siswa dan guru sama -sama bergotong royong dalam melakukan kegiatan di dalam MAN 4 Sleman maupun lingkup sekitaran MAN 4 Sleman. Kaitan ini senada dengan sila 3 dalam Pancasila, karena MAN 4 Sleman menjunjung persatuan dan kesatuan dalam kegiatan yang di lakukan MAN 4 Sleman bersama guru dan siswa maupun lainnya. Sila yang ketiga adalah "persatuan Indonesia", yang dalam pemikiran eksistensialisme berhubungan erat dengan antar sesama manusia, suku, agama, ras dan adat. Dalam hubungan antar sesama manusia, di sini eksistensialisme menggunakan istilah "intersubyektifitas", bahwa eksistensi manusia itu pada hakekatnya bersama dengan orang lain dan pribadi lain ${ }^{[12]}$, manusia tetap tidak mampu bereksistensi secara individual, ini tidak mungkin dan mustahil[13]. Dalam konteks "persatuan Indonesia", masyarakat Nusantara pada masa imperialisme-kolonialisme mengalami ketertindasan yang teramat panjang, dan ini menunjukkan bahwa kita mengalami nasib yang sama, sehingga pada waktu itu muncul kesadaran kolektif untuk bersatu melawan segala bentuk penjajahan terhadap pribumi. Selain faktor imperialisme-kolonialisme, dalam sejarahnya masyarakat kita juga mudah menerima segala bentuk ajaran yang datang dari luar, mulai masuknya Hindu dan Budha sekitar abad ketiga dan keempat, yang mendapatkan momentum terpentingnya pada masa kejayaan Sriwijaya dan Majapahit. Kemudian Islam masuk ke Nusantara sekitar abad ke-13, dengan munculnya berbagai kerajaan Islam di Nusantara. Setelah itu masuklah kemudian agama Kristen, meski agama Kristen masuk melalui VOC yang tampil sebagai perusahaan multinasional pertama di dunia yang secara hegemonik menjalankan fungsi kekuasaan negara selama hampir 200 tahun lamanya $(1620-1800)^{[14]}$, maka harus ada pembedaan antara misi pengembangan agama Kristen dan misi invasi ekonomi, karena sejak awal Kristenisasi di luar orbit kolonialisme. Dari sinilah rasa senasib-seperjuangan itu harus selalu di pupuk dalam konteks "persatuan dalam kebhinekaan", persatuan penyamarataan tidak akan menghapus individualitas manusianya, akan tetapi justru manusia akan lebih menemukan makna eksistensi dirinya manakala mampu untuk bersatu dan mampu untuk saling bereksistensi satu sama lain, karena persatuan adalah kekuatan utama bangsa ini.

Keempat, adanya konstruksi nilai-nilai pancasila yang berdemokratis, jujur, semangat kebangsaan dan cinta tanah air di dalam MAN 4 Sleman. Demokratis yang sering di lakukan MAN 4 Sleman dalam mengimplementasikannya dengan melibatkan warga sekolah dalam setiap pengambilan keputusan secara musyawarah mufakat dan menciptakan suasana sekolah yang menerima perbedaan. Hal ini senada dengan nilai-nilai Pancasila yang terkadung dalam sila ke 4 yang berbunyi "kerakyatan yang dipimpin oleh hikmat 
kebijaksanaan dalam permusyawaratan/perwakilan", yang mana pada sila keempat ini sangat erat kaitanya dengan sikap hidup berdemokrasi, dan dalam kaitannya dengan pemikiran eksistensialisme tentu ini menyangkut kebebasan daripada individu manusia itu sendiri. Bahwa sejak awal eksistensialisme berkomitmen terhadap kebebasan manusia, karena baginya "eksistensi mendahului esensi", dalam artian pertama-tama manusia adalah bebas, bebas dalam menentukan dirinya dan merealisasikan dirinya, inilah eksistensi dari manusia. Dan dalam menjalankan aktifitas kemanusiaannya itulah esensi dari manusia itu sendiri terbentuk, jadi yang membentuk esensi dirinya adalah individu manusianya sendiri, tergantung ingin di bentuk seperti apa esensinya. Dalam hubungannya dengan berdemokrasi, kedaulatan ada di tangan rakyat, bahwa rakyatlah yang berkuasa dan negara harus mendengar aspirasi rakyat. Hatta menambahkan dua anasir lagi dari tradisi demokrasi desa yang asli di Nusantara. "Yaitu hak untuk mengadakan protes bersama terhadap peraturan-peraturan raja yang dirasakan tidak adil,.... dalam melakukan protes, biasanya rakyat bergerombol berkumpul di alun-alun dan duduk di situ beberapa lama tanpa berbuat apa-apa, yang mengekspresikan suatu bentuk demonstrasi yang damai"[15]. Pandangan Nurcholish Madjid dalam Islam, demokrasi erat kaitannya dengan keyakinan tentang ketuhanan, bahwa hanya tuhanlah satu-satunya wujud yang pasti dan selain tuhan bersifat nisbi. Konsekuensinya, setiap bentuk pengaturan hidup sosial manusia yang melahirkan kekuasaan mutlak, di nilai bertentangan dengan jiwa tawhid ${ }^{[16]}$. Demokrasi Indonesia juga mendapat stimulus dari Barat yang lahir dari rahim Revolusi Perancis dengan slogannya, Liberté (kebebasan), égalité (kesetaraan), dan fraternité (persaudaraan), berjuang menggulingkan raja yang di topang oleh kaum ningrat (aristokrat) dan kaum penghulu agama ${ }^{[17]}$, yang semua ini bersifat "humanis-demokratis". Singkatnya, dalam persidangan BPUPKI, pentingnya kedaulatan rakyat dalam semangat kekeluargaan (permusyawaratan), dalam alam Indonesia merdeka mulai dikemukakan sejak sidang pertama pada tanggal 29 Mei 1945[18]. Dalam prinsip musyawarah-mufakat, keputusan tidak didekte oleh golongan mayoritas (mayorokrasi) atau kekuatan minoritas elite politik dan pengusaha (minorokrasi), melainkan dipimpin oleh hikmah-kebijaksanaan yang memuliakan daya-daya rasionalitas deliberatif dan kearifan setiap warga negara tanpa pandang bulu[19].

Kelima, menghargai perbedaan dalam tolak ukur materi di dalam MAN 4 Sleman, sehingga tidak ada perbedaan kelas dalam ruang kelas, pergaulan, fasilitas madrasah dan perbedaan dalam mengayomi siswa oleh guru mata pelajaran. Hal ini di tekankan sekali di MAN 4 Sleman dengan pemerataan dalam tingkat materi atau background orang tua dari murid maupun label materi yang di miliki oleh masing-masing guru ataupun staf karayawan dan di MAN 4 Sleman berdiri koperasi dalam menumbuhkan tingkat perekonomian micro di madrasah. Hal ini senada dengan nilai-nilai Pancasila yang terkadung dalam sila ke 5 yang berbunyi "keadilan sosial bagi seluruh rakyat Indonesia", keadilan sangat erat kaitannya dengan persamaan dan pemerataan, lebih-lebih pada aspek ekonomi. Pemerataan ekonomi akan menciptakan kesejahteraan rakyat, sementara kesenjangan ekonomi mengindikasikan bahwa tengah terjadi ketidakadilan sosial. Dalam hubungannya dengan pendidikan eksistensialisme, di samping manusia itu mempunyai kebebasan, adanya kebebasan mengandaikan bahwa manusia harus bertanggungjawab atas kebebasannya. Manusia bebas menentukan pilihannya, tapi dari semua pilihan yang ada, tidak ada pilihan yang lebih baik selain untuk semua manusia, maka selain bertanggungjawab terhadap dirinya sendiri, pada saat yang sama juga menanggung beban moral untuk bertanggungjawab terhadap semua manusia, bertanggungjawab mewujudkan keadilan sosial bagi seluruh rakyat Indonesia. Maka founding father kita sebenarnya sudah sesuai dalam merumuskan sistem ekonomi "koperasi", kata "koperasi" 
pertama-tama harus dipahami sebagai "kata kerja" (proses), yakni semangat tolong-menolong: semangat kekeluargaan yang senantiasa mengupayakan keuntungan bersama, solidaritas, sosial yang berorientasi, "berat sama dipikul, ringan sama dijinjing"[20]. Sistem ekonomi Pancasila mengandung nilai-nilai keindonesiaan, yaitu kekeluargaan dan kemandirian sebagai jati diri budaya bangsa ${ }^{[21]}$. Rahasia daripada koperasi terletak dari kemauan bekerja sama untuk memperbaiki keadaan ekonomi bersama dasar kerjasama ini adalah self-help dan kesetiakawanan (solidarity), kepercayaan kepada kesanggupan bersama bertambah kuat. Dari individu egois ia menjadi orang sosial yang mulai insaf akan harga dirinya. Dalam koperasi orang seorang tidak hilang keperibadiannya, ia tidak lenyap sama sekali ke dalam suatu kolektifitas sebagai anggota yang tidak bernyawa ${ }^{[22]}$. Hanya di dalam koperasi solidaritas dan individualitas dapat berkembang dalam hubungan harmonis. Koperasi yang senantiasa mendidik dalam jiwa manusia akan rasa tanggungjawab sosial[23]. Karena sumber daya negara yang paling berharga adalah manusia, dan kunci terpenting dalam mengembangkan pemerataan ini adalah peningkatan kualitas sumber daya manusia, dalam perkembangannya, perekonomian Indonesia yang dijalankan sepenuhnya harus untuk kemakmuran rakyat. Pancasila adalah prinsip dan dasar hidup bersama yang disepakati sebagai titik temu, tujuan dan falsafah bangsa, dan karenanya bukan dilihat semata sebagai kompromi kelompok; Pancasila bukan keranjang sampah yang bisa diisi apa saja, karena di dalamnya terkandung falsafah sosial bangsa, dan visi kebangsaan; lima sila itu, menurut Bung Karno adalah meja statis sebagai satu kesatuan, ajeg dan paten, dalam sila persila dan pandangan hidup kebangsaan, sementara penerjemahannya bersifat dinamis yang harus mengacu pada UUD 45 [24]. Oleh karena itu, $\mathrm{KH}$. Abdurrahman Wahid pernah menulis dan menyebutkan bahwa Pancasila sebagai ideologi bangsa: "Pancasila adalah kesepakatan luhur antara semua golongan yang hidup di tanah air kita. Namun, sebuah kesepakatan, seluhur apa pun tidak akan banyak berfungsi jika tidak didudukkan dalam status yang jelas. Karenanya, kesepakatan luhur bangsa kita itu akhirnya dirumuskan sebagai ideologi bangsa dan falsafah negara. Ideologi bangsa, artinya setiap warga negara Republik Indonesia terikat oleh ketentuan-ketentuannya yang sangat mendasar, yang tertuang dalam sila yang lima. Pandangan hidup dan sikap warga negara secara keseluruhan harus bertumpu pada Pancasila sebagai keutuhan, bukan hanya sekedar masing-masing sila. Sebagai falsafah negara, Pancasila berstatus sebagai kerangka berfikir yang harus diikuti dalam menyusun undang-undang dan produk-produk hukum yang lain, dalam merumuskan kebijakan pemerintah dan dalam mengatur hubungan formal antara lembaga-lembaga dan perorangan yang hidup dalam kawasan negara ini. Tata pikir seluruh bangsa ditentukan lingkupnya oleh sebuah falsafah yang harus terus menerus dijaga keberadaan dan konsistensinya oleh negara, agar kontinuitas pemikiran kenegaraan yang berkembang juga akan terjaga dengan baik $^{[25]}$.

Berdasarkan pengamatan peneliti melalui observasi sudah sejalan dengan prinsip-prinsip yang ada dalam sila-sila Pancasila, MAN 4 Sleman sudah di jadikan bentuk pedoman sehari-hari dalam membina program-program yang ada di MAN 4 Sleman seperti Religius, jujur, toleransi, disiplin, kerjasama, kreatif, mandiri, demokratis, rasa ingin tahu, semangat kebangsaan, cinta tanah air, menghargai prestasi, bersahabat komunikatif, cinta damai, gemar membaca, peduli lingkungan, peduli sosial, dan tanggung jawab ${ }^{[26]}$. Beberapa program ini menjadi acuan bagi seluruh peserta didik dan pendidik yang di tugaskan oleh madrasah ${ }^{[27]}$. Wawancara selanjutnya bapak Sudarmoko seorang guru PKN, informan mengungkapkan mengenai cara peserta didik memahami perbedaan antar agama, budaya, dan suku, serta implementasi pendidikan karakter yang di lakukan guru yang berwawasan Pancasila : "Keberhasilan dalam menerapakan nilai-nilai pancasila pada siswa di MAN 4 Sleman, sudah dapat di lihat dan di kembangkan di dalam nilai-nilai sosial siswa dalam 
bersosialisasi di lingkungan sekolah. Karakter dan tingkah laku siswa telah mencerminkan dan mewujudkan nilai-nilai keislaman yang di terapkan siswa di MAN 4 Sleman. Saya sendiri dalam memberikan sebuah pelajaran toleransi bagi siswa di lakukan dengan cara mengaitkan mata pelajaran yang diampuh dengan isu-isu terkini maupun dikaitkan dengan nilai-nilai toleransi, namun tidak semua materi bisa di kaitkan dengan nilai-nilai toleransi. Toleransi sendiri sangat di perlukan bagi siswa mengingat akhir-akhir ini runtuhnya kebersamaan di masyarakat maupun di sekitaran kita akibat melemahnya sikap toleransi yang ada di dalam masyarakat. Oleh sebab itu siswa harus di bekali mengenai nilai-nilai toleransi agar siswa ketika terjun di masyarakat maupun bersosial di masyarakat akan bertindak dan berkarakter seperti seorang yang mengagumi nilai-nilai toleransi bagi sesama umat manusia"[28]. Setelah itu peneliti mewancarai siswa dan siswi kelas $\mathrm{X}$ dan $\mathrm{XI}$ mengungkapkan mengenai cara peserta didik memahami perbedaan antar agama, budaya, dan suku, dalam bingkai Pancasila: "Seluruh elemen siswa-siswi kelas XI IPS $3, \mathrm{XI}$ IPA 2, XII IPS 1, XII IPS 2, X IPA 1, X IPA 2, XI IPA 2 hampir memiliki kesamaan jawaban sepakat dengan mewujudkan nilai-nilai toleransi dalam bersosial di lingkungan sekolah maupun masyarakat. Bagi mereka islam adalah agama yang mencintai kedamaian bukan mencintai perpecahan. Bahkan peneliti sempat menyinggung masalah ideologi Khilafah yang beredar isu nya dari kalangan tua hingga muda, ternyata ada beberapa siswa yang mengikuti isu terkait ideologi khilafah yang akan menggantikan ideologi negara "Pancasila". Jawaban bagi siswa sendiri mereka menolak seruan dari ideologi Khilafah di Indonesia. bahkan mereka membuat istilah "urip ibarat mampir ngombe" (hidup itu ibarat mampir minum). Mereka menjelaskan bahwa jangan aneh-aneh hidup di dunia berbuat baik dan menghormati serta menghargai manusia sudah lebih dari cukup"[29].

Berdasarkan pengamatan peneliti mengenai Hasil Implementasi nilai-nilai pancasila di MAN 4 Sleman. Seperti apa yang sudah di dapatkan peneliti di dalam wawancara dengan kepala madrasah pak Akhmad Mustaqim bahwa di dalam MAN 4 Sleman sudah diterapkan Implementasi nilai-nilai pancasila. Dengan beberapa contoh seperti solat dzuhur berjamaah, adanya diskusi di dalam kelas. Hal ini senada dalam filsafat antropologi manusia yaitu filsafat eksistensialisme yang di kaitkan kedalam sila pertama di Pancasila, yakni "ketuhanan yang maha esa", adalah sejauh menyangkut persoalan "subyektifitas". Dikatakan subyektif karena pengalaman ketuhanan itu merupakan pengalaman kesadaran langsung individu manusia yang sifatnya privat, dan sama sekali tidak bisa disamakan dengan orang lain ${ }^{[30]}$. Karena setiap orang dalam mengeksplorasi pengalamannya pasti berbeda-bada. Meski pengalaman manusia tidaklah sama, termasuk pengalaman langsung tentang ketuhanan, akan tetapi manusia masih bisa saling berbagi tentang pengalaman itu sendiri melalui "komunikasi". Komunikasi mempunyai posisi penting di sini, akan tetapi menjadi lain lagi masalahnya jika persoalan ketuhanan menjadi bahan perdebatan (dalam makna yang negatif), sebab ketuhanan bukan untuk diperdebatkan, melainkan hanya perlu dirasakan kehadiran-Nya dalam jiwa-jiwa kita, di sinilah nilai-nilai dari sila pertama akan mendapatkan tempatnya yang pas bahwa masalah ketuhanan memang sangatlah privat adanya. Dalam ruang publik, sebagaimana negara Indonesia mengakui enam agama beserta Penghayat Kepercayaan yang ada, maka dalam kehidupan beragama tidaklah perlu masing-masing agama saling mengedepankan politik identitas, karena dikhawatirkan akan menimbulkan perpecahan di dalam tubuh NKRI, yang perlu diekspresikan dalam ruang publik adalah esensi dari ajaran agama itu sendiri dan bukan identitas keagamaannya, bahwa setiap agama harus mengalami subtansialisasi ketika berada di ruang publik. Dalam karakter siswa dan siswi yang selalu menghormati dan menghargai guru maupun orang lain di dalam lingkungan sekolah maupun di luar lingkungan sekolah dan di tekankan oleh kepala madrasah agar memiliki prinsip dan 
sikap "Hubbul Wathon Minal Iman", merayakan hari-hari kegaaman, melakukan upacara rutin sekolah, menyelenggarakan peringatan hari-hari besar dan kepahlwanan nasional[31]. Semangat prinsip bela negara sudah ada sejak zaman kemerdekaan, dalam pertempuran di Surabaya pada 10 November 1945 yang saat ini diresmikan menjadi hari pahlawan Nasional. Momen itu tidak terlepas dari pencetusan fatwa resolusi jihad NU oleh $\mathrm{KH}$. Hasyim Asy'ari pada 22 Oktober 1945. Resolusi jihad $\mathrm{KH}$. Hasyim Asy'ari menggerakkan seluruh elemen bangsa untuk mempertahankan kemerdekaan dari agresi militer Belanda kedua yang membonceng sekutu. Ulama NU menegaskan bahwa umat dan ulama di banyak tempat punya hasrat besar untuk menegakkan agama islam dan mempertahankan kedaulatan Republik Indonesia. niat itu tertuang dalam pertimbangan Resolusi Jihad bahwa, mempertahankan dan menegakkan Negara republik Indonesia menurut hukum agama islam, termasuk sebagai salah satu kewajiban bagi tiap-tiap orang muslim[32].

"Hubbul Wathon Minal Iman" di gaungkan pada saat peristiwa itu terjadi yang di cetuskan oleh $\mathrm{KH}$. Hasyim Asy'ari. Dengan semangat kebangsaan yang sudah ada sejak lama menjadi bekal regenerasi dalam meghidupkan api semangat kebangsaan dalam bentuk karya ilmiah dan inovasi baru dalam menjawab tantangan zaman. MAN 4 Sleman memegang prinsip nilai-nilai keislaman dan keindonesia sehingga siswa-siswi tidak hanya saleh spritual akan tetapi saleh sosial dan semangat kebangsaan di dalam sekolah maupun luar sekolah.

Kegiatan observasi peneliti terhadap bentuk kendala-kendala yang di hadapi guru dalam implementasi nilai-nilai pancasila di MAN 4 Sleman. Dalam kegiatan observasi peneliti tantangan dan hambatan yang di alami hanya dalam mentransformasikan nilai-nilai keislaman dan nilai-nilai kepancasilaan ke dalam murid tidak sepenuhnya langsung cepat diserap oleh murid, akan tetapi implementasi yang diajarkan oleh guru-guru kepada murid sudah secara maksimal walaupun masih ada beberapa guru yang mengalami kesulitan dalam memberi ilmu pengetahuan kepada murid tidak maksimal, biasanya guru-guru yang tergolong karena usia yang sudah tidak muda lagi, sehingga keoptimalan dalam mentransformasikan ilmu nya sedikit kewalahann dengan menghadapi siswa yang begitu banyak dalam per-kelas. Dan bagi seorang guru dalam menerapkan nilai- nilai Pancasila adalah saat dalam metode pembelajaran yang menyulitkan siswa dapat cepat dalam memahami penerapan dari impelementasi nilai-nilai kepancasilaan di dalam sekolah maupun di luar sekolah. Ada beberapa hal yang menjadi hambatan juga, hanya pada kurang nya sosialisasi dan pelatihan dalam mempelajari kurikulum yang ada di setiap mata pelajaran yang di ampuh guru nya masing-masing ${ }^{[33]}$. Persoalan ini menjadi kulminasi yang pernah di kritik keras oleh tokoh pendidikan Paulo Freire dengan mengatakan. Sistem pendidikan yang pernah ada dan mapan selama dapat di andaikan sebagai sebuah "bank" di mana pelajar di beri ilmu pengetahuan agar ia kelak dapat mendatangkan hasil dengan lipat ganda. Jadi, anak didik adalah obyek investasi dan sumber deposito potensial. Mereka tidak berbeda dengan komoditi ekonomis lainnya yang lazim dikenal. Depositor atau investornya adalah para guru yang mewakili lembaga-lembaga kemasyarakatan mapan dan berkuasa, sementara depositonya adalah berupa ilmu pengetahuan yang diajarkan kepada peserta didik. Anak didik pun lantas di perlakukan sebagai "bejana kosong" yang akan diisi, sebagai sarana tabungan atau "penanaman modal ilmu pengetahuan" yang akan di petik hasilnya kelak. Jadi, guru adalah subyek aktif, sedang anak didik adalah obyek pasif yang penurut dan di perlakukan tidak berbeda atau menjadi bagian dari realitas dunia yang diajarkan kepada mereka, sebagai obyek pengetahuan teoritis yang tidak berkesadaran ${ }^{[34]}$.

Informan selanjutnya adalah bapak Satria Pratama seorang guru Fiqh dan Aqidah Akhlak. Dalam wawancara peneliti mengungkapkan mengenai bentuk kendala-kendala yang di hadapi guru dalam implementasi nilai-nilai pancasila di MAN 4 Sleman, mengungkapkan : 
"Hambatan mengimplementasikan

dalam penerapan nilai-nilai pancasila yang dilakukan di MAN 4 Sleman, hanya pada kurang nya sosialisasi dan pelatihan dalam mempelajari kurikulum yang ada di setiap mata pelajaran yang di ampuh guru nya masing-masing. Hal-hal seperti inilah yang masih menjadi persoalaan yang dialami guru-guru di MAN 4 Sleman dalam menerapkan kurikulum maupun pendidikan karakter di MAN 4 Sleman dengan baik dan lancar. Hambatan yang terjadi dalam proses pembelajaran dan transformasi yang di lakukan di dalam kelas, kesulitan saya sendiri adalah metode yang di gunakan kadang sulit untuk membuat siswa mengerti selebih-lebih siswa memahami. Dalam hal itulah salah satu hambatan yang saya alami di dalam kelas"[35].

Wawancara selanjutnya bapak Sudarmoko seorang guru PKN, informan mengungkapkan mengenai bentuk kendala-kendala yang di hadapi guru dalam implementasi nilai-nilai pancasila di MAN 4 Sleman, mengungkapkan:

"Hambatan dalam mengimplementasikan nilai-nilai Pancasila, tidak hanya cukup di lakukan oleh setiap guru maupun siswa, akan tetapi kedua-duanya bersama-sama mengimplementasikan nilai-nilai Pancasila itu sendiri. Salah satu gerakan yang sudah ada di MAN 4 Sleman, yaitu solat dzuhur berjamaah. Nah, dari sini tidak semua guru terlibat aktif dalam solat dzuhur berjamaah, kendala ini bukan kendala guru akan tetapi kendala sekolah. Kendala ini di lakukan oleh guru sendiri"[36].

Berdasarkan pengamatan peneliti mengenai bentuk kendala-kendala yang di hadapi guru dalam implementasi nilai-nilai Pancasila di MAN 4 Sleman. Seperti apa yang sudah di dapatkan peneliti di dalam wawancara dengan beberapa informan kepala madrasah, guru aqidah akhlak dan guru PKN bahwa di dalam MAN 4 Sleman hambatan yang pertama mengenai guru dalam memahami kurikulum, metode tranformasi penerapan nilai-nilai Pancasila yang di kaitkan dengan pendidikan yang kurang efektif, pelatihan dan sosialisasi pembekalan pengetahuan guru mengenai nilai-nilai Pancasila yang kurang perlu di tingkatkan, sehingga mampu di serap oleh murid pengetahuan sebanyak mungkin, kalau di ranah peserta didik hanya hambatan yang biasa saja seperti ngobrol dalam kelas, main hp di kelas dan keluar masuk kelas ${ }^{[37]}$ dalam kendala-kendala yang di hadapi oleh seorang guru dalam metode di dalam kelas, dapat di jadikan pedoman dari apa yang membuat suasana kelas menjadi efektif.

Gagasan seorang tokoh pendidikan dapat di jadikan referensi untuk menghadapi metode yang kurang efektif di dalam kelas dengan menggunakan metode "pendidikan hadap masalah" itu guru belajar dari murid dan murid belajar dari guru. Guru menjadi rekan murid yang melibatkan diri dan merangsang daya pemikiran kritis murid. Dengan demikian kedua belah pihak bersama-sama mengembangkan kemampuan untuk mengerti secara kritis dirinya sendiri dan dunia tempat mereka berada. Mereka akan melihat bahwa dunia bukan merupakan realitas yang statis, melainkan suatu proses "menjadi", makhluk yang belum selesai, yang beradaa dalam dan dengan kenyataan yang belum selesai. "Pendidikan hadap masalah" (problem-posing education) senantiasa membuka rahasia realitas yang menantang manusia dan kemudian menuntut jawaban terhadap tantangan itu. Jawaban terhadap tantangan itu membawa manusia kepada dedikasi yang utuh. Pengetahuan adalah keterlibatan. Dalam pendidikan hadap masalah (problem-posing education), yang menekan kan kepada peserta didik untuk sampai pada tingkat tertinggi kesadaran yang di miliki oleh setiap individu yaitu sampai pada kesadaran kritis. Agar peserta didik mampu memecahkan setiap problem yang ada pengetahuan, situasi maupun sampai dunia $^{[38]}$. Dengan menggunakan hal ini dapat kemungkinan besar akan tercipta ruang diskusi yang membebaskan murid dan guru saling belajar satu sama lain agar membuat ruang kelas menjadi efektif dan aktif, sehingga transformasi yang diinginkan oleh guru akan tersalurkan secara komperhensif dan murid akan mendapatkan banyak pengetahuan yang di dapatnya. 
Kebebasan yang di miliki oleh murid di dalam kelas seiring dengan filsafat antropologi yaitu eksistensialisme berkomitmen terhadap kebebasan manusia, karena baginya "eksistensi mendahului esensi", dalam artian pertama-tama manusia adalah bebas, bebas dalam menentukan dirinya dan merealisasikan dirinya, inilah eksistensi dari manusia ${ }^{[39]}$. Dan dalam menjalankan aktifitas kemanusiaannya itulah esensi dari manusia itu sendiri terbentuk, jadi yang membentuk esensi dirinya adalah individu manusianya sendiri, tergantung ingin di bentuk seperti apa esensinya. Dalam hubungannya dengan berdemokrasi yang ada Pancasila dalam prinsip dari aktualisasi yang ada pada sila ke 4 di dalam Pancasila yang berbunyi "kerakyatan yang dipimpin oleh hikmat kebijaksanaan dalam permusyawaratan/perwakilan", yang mana pada sila keempat ini sangat erat kaitanya dengan sikap hidup berdemokrasi," $[40]$. Pandangan Nurcholish Madjid dalam Islam, demokrasi erat kaitannya dengan keyakinan tentang ketuhanan, bahwa hanya tuhanlah satu-satunya wujud yang pasti dan selain tuhan bersifat nisbi. Konsekuensinya, setiap bentuk pengaturan hidup sosial manusia yang melahirkan kekuasaan mutlak, di nilai bertentangan dengan jiwa tawhid ${ }^{[41]}$. Demokrasi Indonesia juga mendapat stimulus dari Barat yang lahir dari rahim Revolusi Perancis dengan slogannya, Liberté (kebebasan), égalité (kesetaraan), dan fraternité (persaudaraan), berjuang menggulingkan raja yang di topang oleh kaum ningrat (aristokrat) dan kaum penghulu agama ${ }^{[42]}$, yang semua ini bersifat "humanis-demokratis.

\section{KESIMPULAN}

Setelah menguraikan panjang lebar dari bab pertama sampai bab akhir, hasil laporan penelitian ini dapat disederhanakan dengan beberapa kesimpulan yang berdasarkan atas hasil uraian dan analisa data yang diperoleh melalui wawancara, observasi, dan dokumentasi yang dijelaskan pada pembahasan tertentu terdahulu sebagai jawaban atas fokus penelitian dan pertanyaan penelitian, maka penulis dapat menarik kesimpulan bahwa :

1. MAN 4 Sleman menerapkan kontruksi filosofis nilai-nilai pancasila di dalam sekolah dengan menggunakan berbagai hal yang di lakukan oleh guru maupun kepala sekolah seperti religius, jujur, toleransi, dispilin, kerja keras, kreatif, mandiri, demokratis, rasa ingin tahu, semangat kebangsaan, cinta tanah air, bersahabat komunikatif, cinta damai, gemar membaca, peduli lingkungan, peduli sosial, tanggung jawab sudah menjadi agenda program pendidikan karakter yang ada di MAN 4 Sleman.

2. Pertama, adanya solat dzuhur berjamaah salah satu pendorong murid dalam menanamkan karakter nilai-nilai keislaman yang tumbuh pada karakter murid yang memiliki akhlakul karimah yang baik. Kedua, saling bergotong royong dalam melakukan aksi peduli sosial maupun memfasilitasi kegiatan yang bersifat sosial. Ketiga, cinta damai, perilaku sopan santun, bersahabat komunikatif dan peduli lingkungan. Hal ini yang tercermin di dalam suasana ketika berada di dalam MAN 4 Sleman yang membuat sejuk dalam pembicaran dialog bersama guru, murid dan staf karyawan MAN 4 Sleman. Keempat, adanya konstruksi nilai-nilai pancasila yang berdemokratis, jujur, semangat kebangsaan dan cinta tanah air di dalam MAN 4 Sleman. Demokratis yang sering di lakukan MAN 4 Sleman dalam mengimplementasikannya dengan melibatkan warga sekolah dalam setiap pengambilan keputusan secara musyawarah mufakat dan menciptakan suasana sekolah yang menerima perbedaan. Kelima, menghargai perbedaan dalam tolak ukur materi di dalam MAN 4 Sleman, sehingga tidak ada perbedaan kelas dalam ruang kelas, pergaulan, fasilitas madrasah dan perbedaan dalam mengayomi siswa oleh guru mata pelajaran. Hal ini di tekankan sekali di MAN 4 Sleman dengan pemerataan dalam tingkat materi atau background orang tua dari murid maupun label materi yang di 
miliki oleh masing-masing guru ataupun staf karayawan dan di MAN 4 Sleman berdiri koperasi dalam menumbuhkan tingkat perekonomian micro di madrasah.

3. Tantangan dan hambatan yang di alami hanya dalam mentransformasikan nilai-nilai keislaman dan nilai-nilai kepancasilaan ke dalam murid tidak sepenuhnya langsung cepat diserap oleh murid, akan tetapi implementasi yang diajarkan oleh guru-guru kepada murid sudah secara maksimal walaupun masih ada beberapa guru yang mengalami kesulitan dalam memberi ilmu pengetahuan kepada murid tidak maksimal, biasanya guru-guru yang tergolong karena usia yang sudah tidak muda lagi, sehingga keoptimalan dalam mentransformasikan ilmu nya sedikit kewalahann dengan menghadapi siswa yang begitu banyak dalam per-kelas.

\section{SARAN}

Saran yang dimaksud adalah sebagai bahan pertimbangan bagi semua pihak dalam rangka perbaikan dan penyempurnaan implementasi pendidikan karakter yang berwawasan pancasila di MAN 4 Sleman Yogyakarta, agar nanti nya MAN 4 Sleman dapat mentransformasikan implementasi pendidikan karakter yang berwawasan pancasila secara optimal dalam menghadapi perkembangan zaman dan pemikiran-pemikiran yang berbahaya masuk ke dalam sekolah-sekolah di Indonesia. Saran-saran tersebut antara lain :

1. Peneliti menghimbau kepada pihak MAN 4 Sleman hendaknya mau mensosialisasikan dan mentranformasikan nilai-nilai Pancasila secara Massif di dalam sekolah maupun mempelajari seminar-seminar mengenai Pancasila di luar sekolah yang digunakan dalam menghadapi perkembangan zaman dan pemikiran-pemikiran yang berbahaya masuk ke dalam sekolah-sekolah, agar guru dan siswa mampu mengembangkan dirinya serta ngimplementasikan nilai-nilai Pancasila di MAN 4 Sleman melalui kreatifitas dan produktifitasnya.

2. Peneliti juga menghimbau kepada pihak MAN 4 Sleman agar lebih optimal dalam mempersiapkan guru agar lebih di tingkatkan dalam mempelajari pendidikan karakter yang di terapkan dalam sudut pandang Pancasila, sehingga ada keseimbangan di anatara implementasi religius dan nasional di MAN 4 Sleman.

3. Guru Harus lebih aktif dalam mencari informasi tentang pembelajaran mengenai Pancasila dan Pendidikan Karakter dalam menyiapkan pendidikan karakter yang berwawasan Pancasila dapat di implementasikan secara optimal di MAN 4 Sleman.

4. Pelatihan wawasan Pancasila bagi guru dan siswa di MAN 4 Sleman di perlukan secara maksimal mengingat perkembangan zaman yang ada sudah harus bertindak dan dipraktekkan bukan hanya di kontektualisasikan saja. Perubahan -perubahan yang terjadi di dunia memang akan terjadi secara alamiah, akan tetapi kita sebagai umat manusia harus mampu mengikuti dan mengembangkan diri dalam menghadapi perubahan zaman yang selalu mengalami dengan pesat.

5. Kepada pihak yang lebih berkompeten agar selalu mengontrol mengenai perkembangan pendidikan di dunia Internasional maupun Nasional. Terlebih isu-isu yang mengancam eksistensi dari Pancasila dan urgensi pemikiran-pemikiran bahaya seperti radikalisme, terorisme dan extremisme yang sudah merabah masuk ke dunia pendidikan.

\section{DAFTAR PUSTAKA}

1. Salahudin A. dan Alkrienchie I.2013.Pendidikan Karakter.Bandung:CV Pustaka Ceria. Hal 30

2. Lingkar Studi.2011.Hasil Survei LaKip "Tentang Kekerasan Bermerek Agama di Kalangan Pelajar". 
http://sc-collection.blogspot.com/201 1/05/hasil-survei-lakip-tentang-keker asan. (Diakses 20 Oktober 2018)

3. Sugiyono, Metode Penelitian Kuantitatif, Kualitatif, dan R\&D, (Bandung: Alfabeta, 2013), hal. 2.

4. Azwar Saifuddin, Metode Penelitian, (Yogyakarta: Pustaka Pelajar, 2007), hal. 5 .

5. Ibid, hal. 7.

6. Sugiyono, Memahami Penelitian Kualitatif, (Bandung: Alfabeta, 2013), hal. 125.

7. Prastowo, Andi, Menguasai Teknik-Teknik Koleksi Data Penelitian Kualitatif, (Yogyakarta: Diva Press, 2010), hal. 289.

8. Satori, Djam'an, Metodologi Penelitian Kualitatif, (Bandung: Alfabeta, 2009), hal. 171.

9. Observasi dokumen MAN 4 di Sleman, 12 November 2019

10. Muzairi, "Eksistensialisme Jean Paul Sartre (Sumur Tanpa Dasar Kebebasan Manusia)", (Yogyakarta : Pustaka Pelajar, 2002), Hal 48.

11. Muzairi, "Eksistensialisme Jean Paul Sartre (Sumur Tanpa Dasar Kebebasan Manusia)", (Yogyakarta: Pustaka Pelajar, 2002), Hal. 50.

12. Muzairi, "Eksistensialisme Jean Paul Sartre (Sumur Tanpa Dasar Kebebasan Manusia)", (Yogyakarta : Pustaka Pelajar, 2002), HIm. 57.

13. Ibid. hlm. 57.

14. Yudi Latif, "Negara Paripurna ( Historisitas, rasionalitas, dan Aktualitas) Pancasila", (Jakarta: PT Gramedia Pustaka Utama , 2011), Hal. 262.

15. Ibid., HIm. 388.

16. Ibid., HIm. 390.

17. Ibid., HIm. 396.

18. Ibid., HIm. 420.

19. Ibid., HIm. 486-487.

20. Ibid., HIm. 588.

21. Ibid., HIm. 592.

22. Ibid., HIm. 593.

23. Ibid., HIm. 594.

24. Rahardjo dan Gusmian, Bung Karno dan Pancasila Menuju Revolusi Nasional. (Jakarta: Galang Exspress : 2002), Hal. 83.

25. Usman dan Alfian. "Pancasila sebagai ideologi dalam berbagai bidang kehidupan bermasyarakat, berbangsa dan bernegara". (Jakarta: BP-7 Pusat Jakarta: 1991), hal. 111.
26. Observasi dokumen MAN 4 di Sleman, 12 November 2019

27. Observasi kegiatan belajar mengajar siswa di kelas $\mathrm{X}, \mathrm{XI}$ dan pengamatan di lingkungan dalam sekolah di MAN 4 Sleman, 10-13 Desember 2019

28. Sudarmoko di Sleman, Tanggal 28 November 2019

29. Siswa-siswi kelas $X$ dan XI di Sleman, Bulan Desember awal sampai pertengahan Desember 2019.

30. Muzairi, "Eksistensialisme Jean Paul Sartre (Sumur Tanpa Dasar Kebebasan Manusia)", (Yogyakarta : Pustaka Pelajar, 2002), Hal 52.

31. Observasi kegiatan belajar mengajar siswa di kelas $\mathrm{X}, \mathrm{XI}$ dan pengamatan di lingkungan dalam sekolah di MAN 4 Sleman, 10-13 Desember 2019.

32. Abdul Mun'in DZ, "Piagam Perjuangan Kebangsaan", (Jakarta: Setjen PBNU-NU Online : 2011), Hal 107.

33. Observasi kegiatan pembelajaran Aqidah Akhlak, Fiqh, PKN dan Quran Hadist kelas X dan XI di MAN 4 Sleman, 13-15 dan 20-22 November 2019

34. Paulo Freire, Pendidikan Kaum Tertindas, Jakarta : Pt. Temprint (LP3ES), 2002, hlm xxi.

35. Satria Pratama di Sleman, Tanggal 7 November 2019

36. Sudarmoko di Sleman, Tanggal 28 November 2019

37. Observasi kegiatan pembelajaran Aqidah Akhlak, Fiqh, PKN dan Quran Hadist kelas X dan XI di MAN 4 Sleman, 13-15 dan 20-22 November 2019

38. Paulo Freire, Pendidikan Kaum Tertindas, Jakarta : Pt. Temprint (LP3ES), 2002, hlm xxii.

39. Muzairi, "Eksistensialisme Jean Paul Sartre (Sumur Tanpa Dasar Kebebasan Manusia)", (Yogyakarta : Pustaka Pelajar, 2002), Hal 5.

40. Yudi Latif, "Negara Paripurna (Historisitas, Rasionalitas, dan Aktualitas) Pancasila", (Jakarta : Pt Gramedia Pustaka Utama, 2011), HIm. 388.

41. Ibid., HIm. 390.

42. Ibid., HIm. 396. 